\title{
PERLINDUNGAN HUKUM TERHADAP KORBAN DALAM TINDAK PIDANA EKSPLOITASI SEKSUAL ANAK (Studi Kasus Putusan Nomor 535/Pid.Sus/2019/PN Dps)
}

\author{
Ade Satriasa Maha Putra, I Nyoman Putu Budiartha, I Made Minggu Widyantara \\ Fakultas Hukum, Universitas Warmadewa, Denpasar-Bali, Indonesia \\ adesatriasa5@gmail.com, budiartha59@gmail.com, mingguwidyantara.fhwjurnal@gmail.com
}

\begin{abstract}
Abstrak
Kasus kejahatan eksploitasi seksual terutama pada anak-anak harus kita waspadai, tidak cukup hanya orang tua saja melainkan pemerintah, masyarakat dan Komisi Perlindungan Anak Indonesia (KPAI) harus ikut berperan dalam menjaga kelangsungan dan perlindungan terhadap anak. Penelitian baru ini bertujuan untuk mengetahui perlindungan hukum terhadap korban dalam tindak pidana eksploitasi seksual pada anak. Jenis penelitian ini adalah penelitian normative dengan pendekatan perundangan-undangan dan pendekatan konseptual. Bahan hukum terdiri dari primer dan sekunder, kemudian dianalisis secara sistematis. Hasil penelitian menunjukkan bahwa perlindungan hukum terhadap anak dari korban eksploitasi seksual diberikan terhadap subyek hukum yang berbentuk dan memiliki sifat preventif atau bersifat represif. Selanjutnya, pengamanan hukum merupakan hal yang mutlak untuk memberikan keadilan, ketertiban, kepastian, kemanfaatan. Sanksi pidana yang diberikan kepada pelaku tindak pidana yakni atas pidana penjara selama 7 (Tujuh) tahun dikurangi selama terdakwa berada dalam masa tahanan dan Pidana akan dikenakan denda sejumlah Rp.100.000.000,- (Seratus Juta Rupiah).
\end{abstract}

Kata Kunci: Perlindungan Hukum, Tindak Pidana, Eksploitasi Seksual Anak, kejahatan seksual

\begin{abstract}
We must be aware of cases of crimes of sexual exploitation, especially in children, it is not enough if parents only but the government, society and the Indonesian Child Protection Commission must take a role in maintaining the continuity and protection of children. This new research aims to determine the legal protection of victims in criminal acts of sexual exploitation of children. This research type is normative research with a statutory approach and a conceptual approach. Legal materials consist of primary and secondary, then analyzed systematically. The results showed that legal protection for children from victims of sexual exploitation was given to legal subjects that had preventive or repressive characteristics. Furthermore, legal safeguards are essential to provide justice, order, certainty, benefit. The criminal sanctions given to the perpetrators of a criminal offense, namely for imprisonment for 7 (seven) years, reduced while the defendant is in detention and the penalty will be subject to a fine of IDR. 100,000,000 (one hundred million rupiah).
\end{abstract}

Keywords: Legal Protection, Crime, Child Sexual Exploitation, sexual crimes

\section{PENDAHULUAN}

Seorang anak sebagai makhluk ciptan Tuhan sejak di dalam kandungan telah memiliki kemerdekan dan kewenangan terhadap hidupnya. Seorang anak berhak mendapat perlindungan dari orang tua, keluarga, masyarakat, bangsa, dan Negara. Oleh karena itu, tiada satu manusia lain atau pihak lain yang bisa merebut hak atas hidup kemerdekaannya. Apabila seorang anak yang masih berada di dalam kandungan dan orang tuanya memiliki niat untuk menggugurkannya maka orang tua tersebut akan mendapatkan hukuman atas perbuatannya. Apalagi jika sang anak yang sudah lahir, dia sudah memiliki hak atas hidup dan sudah memiliki hak merdeka yang tidak bisa diganggu gugat. Sehubungan dengan penjelasan tersebut, mengenai hak seorang anak, banyak terdapat kasus anak yang menjadi korban penindasan seksual khususnya di Indonesia. Tentunya kejadian yang menimpa anak-anak sebagai korban seksual disebabkan oleh beberapa faktor seperti sosial (Lingkungan yang jahat), ekonomi, keluarga, pendidikan dan sebagainya. Sejalan dengan yang dikatakan oleh Rahayu \& Fatoni (2019) bahwa adapun alasan anak menjadi korban eksploitasi seksual komersial karena mereka menjadi korban pemerkosaan, gaya hidup dan perlakuan orang tua. Jika anak-anak menjadi korban eksploitasi seksual biasanya anak tersebut berasal dari kalangan orang miskin dengan pendidikan yang kurang bagus dikarenakan sang 
anak yang sedang bekerja kebanyakan setelah dewasa akan terjebak dengan pekerjaan yang tidak profesional dan dengan rumah yang sangat minim (Usman \& Nacorowi, 2004).

Menurut ILO (2010) bahwa Akibat karena anak tersebut berasal dari keluarga miskin, maka seringkali anak korban pelecehan dan eksploitasi seksual tidak diberikan pendampingan hukum dan tidak dilindungi karena tidak ada pendamping yang ditugaskan kepada mereka. Berdasarkan isu ini, beberapa penelitian serupa dilakukan untuk memberikan solusi terhadap permasalah yang dihadapi seperti pada penelitian ini, diantaranya adalah penelitian yang dilakukan oleh Rizky, Fitriani, Sudibyo, Husnasari, \& Maulana (2019) tentang perlindungan hukum terhadap anak korban eksploitasi seksual komersial melalui media social, selain itu Kurniawati (2014) memberikan fokusan penelitian pada perlindungan hukum terhadap anak korban kekerasan seksual di kota Surakarta, terakhir penelitian tentang perlindungan terhadap anak sebagai korban tindak pidana pedofilia (Multiwijaya, 2019).

Penjelasan di atas menyadarkan kita bahwa tindak pidana eksploitasi seksual anak adalah salah satu masalah sosial yang perlu diawasi dan ditindaklanjuti. Salah satu kasus eksploitasi seksual anak yang benar-benar terjadi di Jalan Sekar Waru 3B Sanur, Denpasar Selatan. Sesuai penyelidikan bahwa kedua tersangka merupakan seorang wanita berinisial NKS (49) dan NWK (51) mereka melakukan eksploitasi manusia atau dalam bentuk yang terkonsep yakni human trafficking kepada anak dibawah umur. Perbuatan yang dilakukan terdakwa diatur dan diancam dalam Pasal 76 I Jo Pasal 83 UU Republik Indonesia Nomor 35 Tahun 2014 Mengenai Perbaikan Atas UU Republik Indonesia Tentang Perlindungan Anak Dengan kejahatan Penjara masing-masing 7 (tujuh) tahun dan akan dikenakan ganti rugi sejumlah Rp. 100.000.000,00 (seratus juta rupiah) yang bisa diganti dengan pidana penjara 6 (enam) bulan. Dari uraian diatas, penelitian yang baru ini bertujuan untuk menganalisis perlindungan hukum atas korban dalam tindak kejahatan eksploitasi seksual anak dan mengetahui hukuman kejahatan terhadap pelaku eksploitasi seksual terhadap anak.

\section{METODE PENELITIAN}

Jenis penelitian ini menggunaka hukum normative. Penelitian hukum normatif ialah penelitian hukum yang dimana konsepnya telah tertulis baik itu dalam perundang-undangan ataupun norma yang menjadi tolak ukur perilaku masyarakat yang wajar (Amiruddin \& Asikin, 2018). Sumber bahan hukum yang digunakan terbagi atas Bahan Hukum Primer adalah bahan hukum yang utama yang menjadi dasar kajian ini. Bahan Hukum sekunder adalah adalah bahan hukum yang digunakan untuk menunjang atau membantu dalam memberikan pemahaman- pemahaman dan gambaran-gambaran serta teori-teori hukum yang di gunakan untuk mengulas dan memecahkan persoalan-persoalan yang akan di teliti di dalam penelitian ini.

\section{HASIL DAN PEMBAHASAN}

\section{Perlindungan Hukum terhadap Korban dalam Tindak Pidana Eksploitasi Seksual Anak}

Perlindungan hukum adalah sebuah gambaran dari bekerjanya pengertian dari peranan hukum untuk mewujudkan target hukum yang diinginkan, yang terdiri dari keadilan, kemanfaatan, dan kepastian hukum perlindungan hukum merupakan sebuah pertahanan ditunjukan pada subjek hukum sesuai dengan peraturan yang berlaku, baik peraturan yang bersifat preventif (pencegahan) atau peraturan yang bersifat represif pemaksaan, baik tertulis maupun tidak tertulis di dalam rencana memberdirikan peraturan hukum. Menurut, Suartana \& Darma (2020) bahwa perlindungan hukum berarti melindungi hak asasi manusia yang dirugikan oleh orang lain dan perlindungan tersebut diberikan kepada masyarakat agar dapat menikmati semua hak yang diberikan oleh undang-undang. Perlindungan hukum bagi rakyat mencakup diantaranya: Pertama, perlindungan preventif adalah bentuk perlindungan hukum yang memberikan jalan terhadap rakyat dalam mengajukan keberatan memberikan pernyataannya sendiri sebelum sebuah keputusan pemerintah dijatuhkan atau berbentuk definitive. Yang kedua, perlindungan hukum yang represif, merupakan sebuah bentuk perlindungan yang lebih ditunjukkan dalam penyelesaian konflik (Hadjon, 1987). Seperti yang tertulis dalam Undang-undang bahwa rakyat Indonesia memiliki sebuah perlindungan hukum yang merupakan penerapan atas prinsip dari sebuah pengakuan dan perlindungan atas harkat dan martabat manusia yang berasal dari Pancasila. Menurut Liyus (2020) bahwa anak-anak dari korban perkosaan di Indonesia dilindungi hak mereka dan ditentang segala bentuk kekerasan terhadap anak. Pengaturan hukum di Indonesia diatur dalam berbagai undangundang antara lain Undang-Undang Nomor 35 Tahun 2014, Undang-Undang Nomor 31 Tahun 2014, Undang-Undang Nomor 11 Tahun 2012, KUHP, Konsep KUHP dan Hukum Pidana. 
Definisi dari eksploitasi seksual pada anak dibagi menjadi tiga yakni eksploitasi, seksual, dan anak. Semua bagian itu akan dijelaskan terpisah dan pada akhirnya akan menjadi satu. Arti dari eksploitasi ialah penggunaan untuk keuntungan pribadi pengisapan, penindasan terhadap tenaga orang lain. Dan arti dari eksploitasi menurut terminology ialah keinginan pada seseorang untuk memanfaatkan orang lain demi kepuasan orang pertama tanpa menghiraukan kebutuhan pribadi orang kedua.

Berikut merupakan contoh perbuatan eksploitasi adalah pemanfaatan seksual anak dideskripsikan sebuah gerakan yang melibatkan anak laki-laki dan perempuan agar mendapatkan pundi-pundi rupiah, dan kesenangan sebuah pihak, manfaat atau evaluasi lain atau dikarenakan sebuah pemaksaan atau dampak dari orang dewasa, oknum, sindikat berhubungan seksual atau memiliki perilaku yang menyebabkan keinginan untuk berhubungan seksual. Ada 3 kegiatan yang termasuk dalam kategori eksploitasi seksual ialah: Prostitusi anak, Perdagangan anak dan Pornografi anak (Liana, 2013).

Pelaku kejahatan memberdayakan anak dan bahkan mengeksploitasinya secara seksual komersial karena anak mudah untuk dirayu dan belum memiliki pemikiran yang luas dan dalam. Anak adalah kelompok rentan yang sering dimanfaatkan oleh para pelaku kejahatan. Tipu muslihat dan iming-iming uang, mainan dan boneka biasanya dilakukan oleh para pelaku kejahatan yang menargetkan anak dibawah umur. Eksploitasi seksual komersial anak ialah pelanggaran terhadap hak anak dan meliputi tindakan-tindakan kejahatan yang menjatuhkan dan menggertak integritas fisik dan psikososial anak.

Secara umum dapat dikatakan perlindungan anak bisa dibedakan menjadi dua pengertian, yakni perlindungan anak yang bersifat yuridis dan non yuridis (Gosita, 1983). Perlindungan anak yang bersifat yuridis melibatkan seluruh peraturan hukum yang memiliki akibat langsung terhadap kehidupan anak, dalam artian seluruh peraturan hukum yang mengatur mengenai kehidupan seorang anak. Hukum tertulis dan non tertulis masih berlaku di Indonesia, sehingga ruang lingkup perlindungan anak yang memiliki sifat yurdis ini juga memiliki ketentuan-ketentuan hukum adat.

Menurut Fatahillah (2010) bahwa pengamanan yang diinformasikan oleh Kitab Undang undang Hukum Pidana kepada anak ialah sebagai berikut.

a. Menjaga Kesopanan Anak

Pasal 283 mengekang seseorang yang menawarkan, menyewakan baik yang bersifat sesaat atau selamanya, memberitahukan di tangan atau memperlihatkan sebuah tulisan, gambar, barang yang menyinggung perasaan. Contohnya sebuah lukisan bertema pornografi, tulisan yang bersifat porno atau alat-alat kontrasepsi tidak boleh dijual kepada anak-anak termasuk isi surat yang tidak sopan, dan tahu memperlihatkan surat yang tidak sopan kepada orang. Apabila hal-hal tersebut terjadi dan ditujukan kepada anak maka hal itu dapat mengganggu cara berpikir anak sehingga dapat menyebabkan anak kesulitan menerima pelajaran ataupun ilmu dan wawasan baik dari sekolah maupun pendidikan non formal. Anak membutuhkan perlindungan untuk keberlangsungan kehidupannya yang baik secara psikologis maupun mental.

b. Larangan Bersetubuh dengan Orang yang Belum Dewasa

Pasal 287 KUHP, tidak diperbolehkan bersetubuh dengan perempuan dibawah umur atau yang belum menginjak usia 15 (Lima belas) tahun baik perbuatan yang dilakukan atas dasar suka sama suka antar pelaku maupun secara paksa oleh pelaku. Anak adalah generasi penerus bangsa. Anak masih berumur dibawah 18 tahun, anak berhak mendapatkan perlindungan dari segala macam eksploitasi terhadapnya.

c. Larangan Berbuat Cabul terhadap Anak

Pasal 290 KUHP tidak memperbolehkan semua manusia berbuat pencabulanl dengan seseorang yang masih dibawah umur baik anak laki-laki ataupun anak perempuan yang dalam keadaan tidak sadarkan diri. Pelarangan juga berlaku bagi mereka yang melakukan pencabulan terhadap seseorang yang dibawah umur. Apalagi perbuatan mengajak dan merayu anak yang belum berusia 15 (Lima belas) tahun atau mengizinkan aksi pencabulan, atau untuk berbuat mesum dengan orang lain.

d. Dilarang Menculik Anak

Pasal 330 KUHP menentukan bahwa idak memperbolehkan setiap orang dalam membawa kabur seseorang baik itu anak laki-laki maupun anak perempuan dari keluarganya.yang tergolong belum berinjak dewasaa dalam menurut pasal ini ialah mereka yang belum genap berusia 21 tahun yang belum pernak melakukan perkawinan/menikah.

e. Larangan Menyembunyikan Orang Yang Belum Dewasa 
Ada Kalanya di dalam implementasi seseorang yang belum dewasa (dalam hal ini pada usia 21 tahun) mencabut/cabut dari yang bertanggung jawab terhadapnya atau diambil haknya dari orang tuanya atau yang bertanggung jawab terhadap dirinya.

f. Larangan Melarikan Perempuan Belum Dewasa

Pasal 332 KUHP menentukan bahwa tidak memperbolehkan siapapun melarikan perempuan yang masih dibawa umur (belum berusia 21 tahun) tidak juga atas keinginan orang tua atau walinya, akan tetapi harus melalui persetujuan sang anak apakah dia ingin menikah atau tidak menikah.

Berdasarkan Pasal 64 ayat (3) UU Nomor 23 Tahun 2002 mengenai Perlindungan Anak menentukan bahwa pengamanan khusus terhadap anak yang menjadi korban tindak pidana dilakukan dengan cara:

a. Upaya pembaharuan, baik yang dilakukan dalam sebuah lembaga maupun di luar lembaga;

b. Upaya pengawasan dari pemberitahuan identitas dengan jalan media massa dan supaya bisa menghindari labelisasi;

c. Pemberian perlindungan keselamatan para saksi korban dan juga saksi ahli, baik perlindungan secara fisik, mental, maupun sosial; dan

d. Pemberian dan menjembatani mengenai informasi dan perkembangan perkara yang sedang terjadi.

\section{Sanksi Pidana terhadap Pelaku Tindak Pidana Eksploitasi Seksual terhadap Anak}

Sanksi Pidana merupakan hukuman dari sebab akibat, sebab merupakan kasusnya sedangkan akibat ialah hukumnya, seseorang yang mendapat akibat akan mendapatkan hukuman masuk penjara atau menerima hukuman lainnya dari kepolisian. Hukuman kejahatan pada dasarnya ialah penanggung jawab demi membenahi dari pelaku kejahatan tersebut, akan tetapi tidak jarang bahwa sanksi hukuman dibuat hendaknya suatu ancaman dari kebiasaan manusia itu sendiri (Andrisman, 2009).

Kasus yang dibahas dalam penelitian ini mengenai tindak eksploitasi terhadap anak sebagai berikut. Pertama, yang dilakukan terdakwa Ni Wayan Aristiani alias Mami Wayan. Kedua, Ni Komang Sucitawati alias Bu Komang Suci dan terbukti sebagai sebagai pelaku, yang menginstruksikan melakukan atau yang ikut melakukan perbuatan menawarkan pekerjaan sebagai cewek Open Booking Out (BO) yang berada di sekitaran terdakwa. Tindakan yang melanggar hukum Perlindungan Anak yang diatur dan diancam kejahatan dalam Pasal 76 I Jo. Pasal 88 UU Republik Indonesia Nomor: 35 Tahun 2014 tentang Perubahan atas Undang Undang Republik Indonesia No. 23 Tahun 2002 tentang Perlindungan Anak dalam Dakwaan Ketiga.

Dalam putusan perkara kejahatan Pengadilan Negeri Denpasar Nomor 535/Pid.Sus/2019/PN Dps memberitahukan bahwa secara sah dan membuktikan bersalah melakukan Tindak Pidana " menempatkan, membiarkan, turut serta melakukan penggunaan secara ekonomi dan/atau seksual terhadap anak " yaitu yang di diatur dalam Pasal 76 I Jo. Pasal 88 Undang-Undang Republik Indonesia Nomor: 35 Tahun 2014 perihal Perubahan atas Undang-Undang Republik Indonesia No. 23 Tahun 2002 Atas Perlindungan Anak dalam Dakwaan Ketiga. dengan hukuman selama 7 (Tujuh) tahun dan dikurangi masa tahanan dan denda sejumlah Rp. 100.000.000,- (seratus juta rupiah) jika Denda tidak mampu di bayar maka akan digantikan dengan hukuman kurung selama 6 (Enam) bulan, dan Restitusi sebesar Rp 144.192.000,- (Seratus Empat Puluh Empat Juta Seratus Sembilan Puluh Dua Ribu Rupiah).

\section{SIMPULAN DAN SARAN}

\section{Simpulan}

Dari hasil analisis di atas dapat kita simpulkan bahwa (1) perlindungan hukum terhadap anak dari korban eksploitasi seksual diberikan terhadap subyek hukum yang berbentuk dan memiliki sifat preventif atau bersifat represif, yang secara lisan atau secara tertulis. Dan bisa diinformasikan perlindungan hukum bak suatu gagasan individual dari peran hukum, yang mempunyai rancangan hukum dapat memberikan sebuah ketertiban, keadilan, kemanfaatan, kepastian. Pencabulan termasuk ke dalam penggolongan jenis tindak pidana kesusilaan sebagai halnya yang diatur didalam Pasal 76 I Jo. Pasal 88 UU Republik Indonesia Nomor 35 Tahun 2014 perihal Perubahan atas Undang-Undang Republik Indonesia No. 23 Tahun 2002 perihal Perlindungan Anak. Kemudian, (2) Sanksi bagi pelaku eksploitasi seksual pada anak yang dimuat didalam Pasal 76 I Jo. Pasal 88 UU Republik Indonesia Nomor 35 Tahun 2014 Perihal Perbaikan terhadap UU Republik Indonesia No. 23 Tahun 2002 yang 
mengatur Perlindungan Anak dengan hukuman penjara selama 7 (Tujuh) tahun yang akan dikurangi masa tahanan dan Pidana Denda sejumlah Rp. 100.000.000,- (Seratus Juta Rupiah).

\section{Saran}

Melalui penelitian ini diharapkan kepada Pemerintah sebagai pejabat yang memiliki kewenangan, mestinya mengkaji ulang Undang-Undang Perlindungan Anak terkait denda pada pelaku eksploitasi seksual terhadap anak, agar hal tersebut tidak terulang kembali agar memberikan efek jera bagi pelaku eksploitasi seksual anak. Kemudian, kepada penegak hukum seperti aparat kepolisian, kejaksaan dan peradilan agar memberikan putusan setimpal sesuai dengan ketentuan Undang-Undang bagi pelaku eksploitasi terhadap anak supaya tidak ada lagi anak sebagai sasaran kejahatan seksual terutama eksploitasi seksual anak.

\section{DAFTAR PUSTAKA}

Amiruddin, \& Asikin, Z. (2018). Pengantar Metode Penelitian Hukum. Jakarta: Rajawali Pers.

Andrisman, T. (2009). Asas-Asas dan Dasar Aturan Hukum Pidana Indonesia. Bandar Lampung: Unila.

Fatahillah. (2010). Perlindungan Hukum Terhadap Anak Sebagai Korban Tindak Pidana Kesusilaan Yang Dilakukan Oleh Anak. Universitas Muhammadiyah Yogyakarta.

Gosita, A. (1983). Masalah Korban Kejahatan. Jakarta: CV. Akademika Pressindo.

Hadjon, P. M. (1987). Perlindungan Hukum Bagi Rakyat di Indonesia: Sebuah Studi tentang Prinsip-Prinsipnya, Penanganannya oleh Pengadilan dalam Lingkungan Peradilan Umum dan Pembentukan Peradilan Administrasi Negara.

ILO. (2010). Improving the Legal Protection of Child Victims of Sexual Abuse and Exploitation: Analytical Report.

Kurniawati, A. (2014). Perlindungan Hukum Terhadap Anak Korban Kekerasan Seksual Di Kota Surakarta (Studi Kasus Pelayanan Terpadu Perempuan dan Anak Surakarta). Recidive: Jurnal Hukum Pidana Dan Penanggulangan Kejahatan, 3(2), 115-123.

Liana, R. (2013). Tindak Pidana Eksploitasi Seksual Anak. Universitas Jenderal Soedirman.

Liyus, H. (2020). Legal Protection for Children Victims of Rape Comparative Study Between Indonesia and Malaysia. Riau Annual Meeting on Law and Social Sciences (Ramlas 2019), 442(September 1985), 6-11.

Multiwijaya, V. R. (2019). Perlindungan Terhadap Anak Sebagai Korban Tindak Pidana Pedofilia. Hukum Pidana Dan Pembangunan Hukum, 1(2).

Rahayu, D., \& Fatoni, S. (2019). Commercial Sexual Exploitation of Children: An Effort of Handling and Legal Protection. Yustisia Jurnal Hukum, 8(2), 330-353.

Rizky, M. N., Fitriani, R. I., Sudibyo, M. W., Husnasari, F. A., \& Maulana, F. (2019). Perlindungan Hukum Terhadap Anak Korban Eksploitasi Seksual Komersial Melalui Media Sosial. Media Iuris, 2(2), 197.

Suartana, K., \& Darma, I. M. W. (2020). Legal Protection Against Children Victims of Sexual Violence in the Directorate General Criminal Agency-Polda Bali. Jurnal Kertha Semaya, 8(12), 1963-1971.

Usman, H., \& Nacorowi, N. D. (2004). Pekerjaan Anak di Indonesia. Jakarta: Grasindo. 